\title{
Anatomy of Lumbar Interspinous Ligaments: Attachment, Thickness, Fibre Orientation and Biomechanical Importance
}

\author{
Anatomía de los Ligamentos Interespinosos Lumbares: Inserción, \\ Grosor, Orientación de las fibras e Importancia Biomecánica
}

Niladri Kumar Mahato

MAHATO, N. K. Anatomy of lumbar interspinous ligaments: attachment, thickness, fibre orientation and Biomechanical importance. Int. J. Morphol., 31(1):351-355, 2013.

SUMMARY: Literature related to the study of interspinous ligament in the lumbar region is sparse. Very few studies have elucidated the fibre orientation of this ligament at different lumbar levels. Male (19) and female (6) cadavers were dissected to expose the interspinous ligaments beneath all the lumbar vertebrae. Fibre attachments and directions were observed at all lumbar interspinous spaces. Thicknesses of the ligaments were measured at all levels. Interspinous ligament fibres were found to be oriented differently in the lumbar inter-spinous spaces. In the upper spaces the fibres were more horizontal. In the spaces beneath L3 and L4, fibres were curved and extended postero-superiorly. Fibres were thicker in the ligaments at the lower spaces in comparison to the upper ones. The mean thicknesses presented as: Upper $(0.22 \mathrm{~mm})$; Middle $(0.37 \mathrm{~mm})$ and L5-S1 $(0.72 \mathrm{~mm})$. Ligaments in the females were slightly thinner in comparison to the males. Fibres of inter-spinous ligaments were also found to attach to the inner aspects of the supraspinous ligament. Ligaments at L5-S1 junction were relatively vertical and stronger. None of the specimen demonstrated absence or cavitations of these ligaments except in a case with bi-laminar ligament at the L3-L4 level. The anatomy of the interspinous ligaments points to their probable role in graded restricting of acute flexion at the lumbar spine.

KEY WORDS: Lumbar flexion; Spinous process; Supraspinous ligament.

\section{INTRODUCTION}

The inter-spinous ligaments (ISLs) are sheets of fibrous tissue that extend between spines of vertebrae throughout the vertebral column. These ligaments vary from being quite thin in the cervical region, rounder in the thoracic spine and characteristically broader and thicker in the lumbar vertebral segments (White \& Punjabi, 1978; Apsden et al., 1987). ISL at the lumbar region have been observed to be stretched during movements at the lumbar and lumbo-sacral spine. The ISL is exposed to increasing tension with increasing degree of flexion at the lumbar spine. Full flexion at the lumbar spine caused the maximum tension within the ISL (Silver, 1954). The resistance offered by the ISL to flexion helps in controlling graded bending of the lumbar spine at segmental levels (Adams et al., 1980). The ISL are probably also subject to compressive forces developed between the lumbar vertebral spines during extension at the lumbar region and to obliquely directed stretch during axial rotation of the lower spine. The compressive forces acting on the ISL are probably of insignificant consequence as these ligaments can simply loosen-up during an axial compressive stress. Though quite a few studies have described the structural and functional properties of these ligaments, detailed observations of ISL at the lumbar region are few (White \& Punjabi; Tesh et al., 1987; Myklebust et al., 1988; Pintar et al., 1992; Hukins \& Meakin, 2000).

The paucity of literature pertaining to the structure of ISL is evident from the fact that there are barely more than a couple of reports that comment on the orientation of the fibres in the ISL, their strength and on their bio-mechanical implications, as referred above. A detailed account of interspinous and inter-transverse ligaments is provided by Heylings (1978). This study demonstrates that the fibers in the ISL stretched from the base of the spine of the lower vertebra upwards and backwards (postero-superiorly) to get attached to the tip of the spinous process of the vertebra above. ISL also inserts into the inner aspects of the supra-spinous ligament and to the thoraco-lumbar fascia. The directionality of the ISL observed in the study explains the fact that the ISL is liable to be put under stretch duress in flexion at the lumbar region. The fibres within ISL possess poor elastic elements and may give way in extreme of lumbar spinal flexion (Myklebust $e t$ al.; Scapinelli et al., 2006) a fact that bears direct relationship 
with the directionality of the ISL fibres demonstrating their sinuous course and poor presence of elastic elements. The typical orientation of the ISL fibres resists a posterior translation of lumbar vertebrae, especially in situations where the lumbar spine is hyper-extended with the upper torso bend backwards beyond the vertical plane. The ISL is thicker in the lumbar spine possibly due to the increased forces (loading) sustained in these ligaments during flexion movements at the lower back (Noyes et al., 1974). The ISL at the thoracic region is not exposed to higher degrees of flexion loading. Though the cervical spine is subject to a lot of bending moments in all the planes, ISL at the cervical region is thinner due to the presence of the ligamentum nuchae that absorbs majority of flexion stretch generated at the posterior elements of the cervical spine. The present study was undertaken to observe (1) the orientation of the fibres in ISL at the different interspinous lumbar segments and (2) analyse their bio-mechanical importance in regulating the moments at different lumbar vertebral levels.

\section{MATERIAL AND METHOD}

This study was based on cadaveric dissection done in twenty human lumbar regions. The material for dissection belonged to persons from both sexes (male $=14$; female $=6$ ) and from age group 45-70 years, obtained from specimens used for teaching undergraduate medical students in the central and southern states in India. All specimens were dissected to expose the interspinous ligaments (ISL) below the first lumbar vertebra, including the ligament at the L5$\mathrm{S} 1$ junction. All interspinous areas were cleaned after removal of the interspinous and the intertransverserii muscles from both sides of the vertebral spines. The ISLs were identified and the directions of their fibres noted. Transverse ISL thickness at all the inter-vertebral levels were measured with the help of digital vernier calipers [sensitivity $=0.01 \mathrm{~mm}$ ] and compared between the vertebral levels for analysis. ISLs at the two inter-vertebral spaces below L1 and L2 were designated as the Upper space fibres, the ISLs below L3 and L4 as the Middle space fibres and those at the L5-S1 spaces as Lower fibres. Measures for all ISLs in each of these groups of fibres were recorded as the average for that group.

\section{RESULTS}

Careful observation of the orientation of the fibres in ISL revealed that: (1) the fibres changed their directions gradually, as one observed the ISLs within the interspinous spaces sequentially downwards; (2) The ISL fibres at the upper spaces (below L1 and L2 vertebrae), were horizontally disposed (Fig.1a). (3) Majority of ISL fibres at the middle spaces (below L3 and L4) extended postero-superiorly from the base of the upper surfaces of the lower spine to the lower margins of the spinous process (towards the tip of the spine) of the vertebra above (Fig.1b). (4) Fibres at the L5-S1 space were almost vertically oriented (Fig. 1c). In the upper and middle spaces only few fibres were seen to arise from the upper margin of the lower spines.

The ISL at the upper two spaces were thinner in dimension $(0.22 \mathrm{~mm})$. The fibres of the ISL in these spaces originated predominantly from near to the base of the upper margin of the spinous process of the lumbar vertebra below. The fibres were directed backward and upward and traversed the interspinous space almost horizontally (Fig.1a). The upper ends of about $1 / 3$ rds of these fibres (anterior ISL fibres) in the spaces were inserted to the distal part of the lower margin of the spinous process of the vertebra above. Majority of the fibres formed the posterior $2 / 3$ rdsof the ISL in the spaces. These posteriorly situated fibres ran posterosuperiorly in an oblique direction and were inserted into the inner aspect of the supraspinous ligament. The ISL at middle spaces (below L3 and L4) possessed comparatively thicker bundles of fibres $(0.37 \mathrm{~mm})$. Entire set of these fibres originated across the length of the upper margin of the spinous process of the vertebra below. These fibres were directed postero-superiorly, as reported earlier (Heylings). These fibres were seen to acutely change their direction midway through the interspinous spaces to acquire a more horizontal disposition (Fig.1b). The fibre bundles presented a loop (with concavity directed dorso-inferiorly) at the junction of the change in direction of the fibres as has been reported earlier (Scapinelli et al.). Almost all the fibres from the middle interspinous spaces (below L3 and L4) were found to be inserted into inner aspect the supra-spinous ligament. Very few fibres in the upper part of the space however were inserted neat the tip of the spine of the vertebra above.

ISL fibres at the L5-S1 junction were oriented almost vertically (Fig. 1c). The fibres originated at the tips of the median sacra crest (fused spinous elements of the sacral segments). The fibres ascended up almost vertically due to the anatomical angular orientation of the sacrum with respect to the fifth lumbar vertebra. The vertical orientation of the ISL fibres was found accentuated in the female specimen. The coronal disposition of the ISL at its attachment to the median sacral crest was longer than that in the other spaces. The anterior parts of these ISLs were inserted to the broad undersurface of the L5 spinous process. The posterior segments of the L5- S1 ISLs were attached along the inner aspect of the supraspinous ligament at that space. The average thickness of the L5-S1 ISLs measured $0.72 \mathrm{~mm}$. 

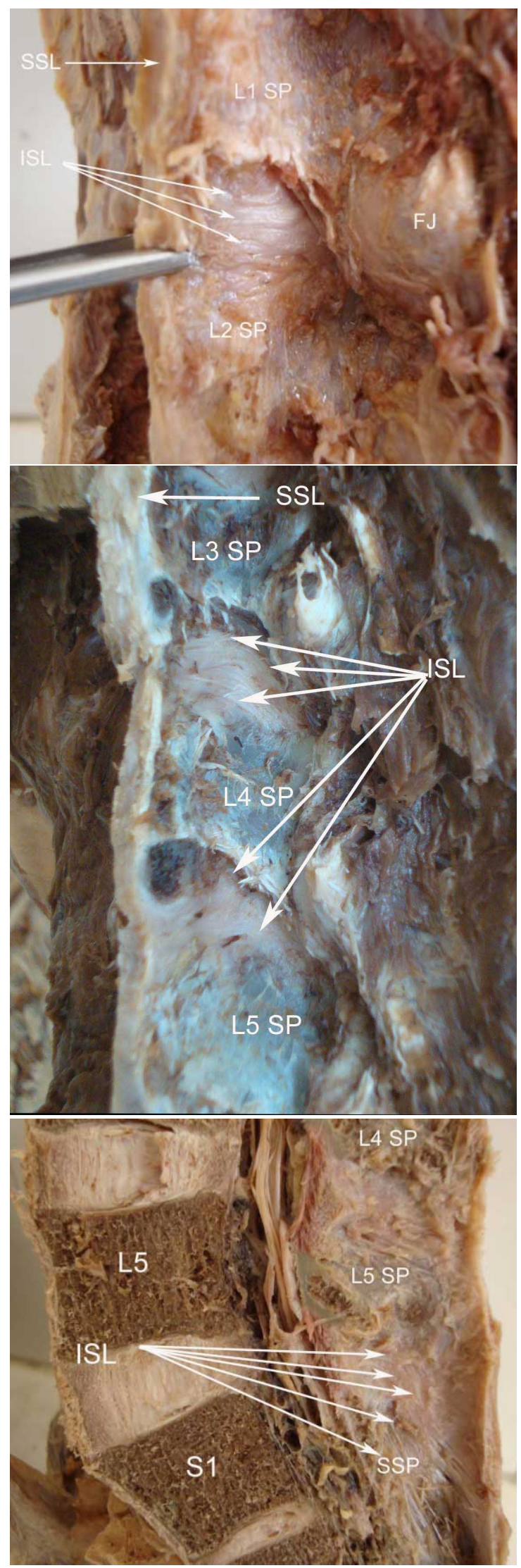

The female ligaments were observed to be slightly thinner than their male counterparts, measuring $0.19 \mathrm{~mm}$ and $0.33 \mathrm{~mm}$ at the upper and middle levels. The average thickness of the L5-S1 segments of ligament in both the sexes measured almost the same with two of the female specimens measuring above the average calculated in the males. Four of the male samples exhibited gross thinning of the thickness of the ISLs in the upper level and three in the middle spaces. One of the male L3-L4 spaces demonstrated a bifid arrangement of fibres extending from the origin to the insertion of the ligament. None of the spaces showed any cavitation, rupture or absence of fibres. The average thickness of the upper, middle and the Lower (L5-S1) ISLs measured were $0.22 \mathrm{~mm}, 0.37 \mathrm{~mm}$ and $0.72 \mathrm{~mm}$ respectively. The lower fibres were seen to blend with the supra-spinous ligament as well as with the thick thoraco-lumbar fascia covering the erector spinae muscle bi-laterally.

\section{DISCUSSION}

Rissanen (1960) in his exhaustive study put forward certain interesting anatomic observations about the ISL. These observations were based on dissection of the ISL in 306 specimens that included cadavers ranging from foetal to 90 years age group specimens, with good numerical representations from within the range. He observed that 21 percent of all specimens above 21 years of age presented with rupture of one or more of the ISLs; mostly between the L4-L5 and the L5-S1segments. It was further found that about $3 / 4^{\text {th }}$ of the samples between 31-40 years of age exhibited cavitations at the ISL. These facts indicated that the ISLs were hardly the structures with significant contributors to the stability at the lumbar spine. The limited functional significance of the ISLs has also been pointed out by researchers in context of the cervical spine (Bedbrook, 1969), sometimes with their occasional absence (Halliday et al., 1964). This issue has, nevertheless, also been contested by other studies that have demonstrated the structural and functional importance of this structure in sharing load, especially in the later part of normal lumbar flexion (Hindle et al., 1990) or during traumatic events at the lower spine (Holdsworth, 1963).

The present study demonstrated that the fibres of ISL were directed more horizontally at the upper and middle vertebral levels at the lumbar region (Fig.1a and b). This probably implied that the ligaments at these inter-spinous spaces (at the upper part of the lumbar curvature) were oriented in a fashion that possibly did not resist flexion as much it could prevent a posterior translation of the upper vertebra. This probably allowed a greater range of flexion at the upper lumbar motion segments; not being intruded by inducing tension in

Fig. 1. (a) Interspinous ligament (ISL) at the upper spaces. Note the horizontal orientation of the fibres. (b) ISL at the middle spaces. Note the arching of the fibres postero-superiorly. (c) ISL at the L5-S1 junction viewed from the inner aspect. Observe the vertical orientation of the ISL fibres. SP= Spinous Process; $\mathrm{FJ}=$ Facet Joint; $\mathrm{SSL}=$ Supraspinous ligament; $\mathrm{SSP}=\mathrm{Sacral}$ spinous process. 
the more horizontal ISL fibres. The lower (L3-L4 and L4-L5) ISLs were directed more obliquely. Their postero-superior direction resisted both flexion as well as a posterior displacement of the superior vertebra by the vectors generated by the oblique pull developed in the ligament. Though ISL are the first ligaments to rupture in lumbar flexion beyond physiological limits, the main elements that resist lumbar flexion were the inter-vertebral discs, the facet capsules and the ligamentum flava (Apsden et al.). The ISL at the L5-S1 junction was seen to be positioned almost vertically between the smaller sloping spines at the dorsum of sacra and the lower surface of the stout spinous processes of the L5 vertebrae. Orientations of these fibres were most likely to maximally resist flexion at the L5-S1 junction in the sagittal plane. The normal lumbo-sacral junction is already angulated in such a way that it possibly has the minimum risk of suffering a posterior translation. As a result, all the ISL fibres have been aligned to prevent excessive flexion and possible lumbo-sacral facet dislocation at the L5-S1 junction, which is quite possible in case extreme bending at the lumbar segments of the spine.

\section{CONCLUSION}

It could be thus understood that fibres in the interspinous ligaments (ISL) at different levels are aligned at different directions. The directions of fibres gradually change from horizontal to vertical through the inter-spinous spaces, as one goes from the upper spaces towards the lower ones. The ISL fibres also possess different thicknesses at different levels of the lumbar spine and possibly serve diverse functions according to their orientation and thickness.

\section{ACKNOWLEDGEMENTS}

Author acknowledges appreciation for logistic and material help provided by SAIMS, Indore and SRM Medical College, Chennai, India.

MAHATO, N. K. Anatomía de los ligamentos lumbares interespinosos: Unión, grosor, orientación de las fibras e importancia biomecánica. Int. J. Morphol., 31(1):351-355, 2013.

RESUMEN: La literatura relacionada con el estudio del ligamento interespinoso en la región lumbar es escasa. Pocos estudios han permitido comprender la orientación de las fibras de este ligamento en diferentes niveles lumbares. Fueron disecados cadáveres de 19 hombres 6 y mujeres para exponer los ligamentos interespinosos debajo de las vértebras lumbares. La unión de las fibras y su dirección se observó en todos los espacios interespinosos lumbares. El grosor de los ligamentos se midieron en todos los niveles. Las fibras del ligamento interespinoso se encontró orientada de manera diferente en los espacios lumbares interespinosos. En los dos espacios superiores las fibras eran más horizontales. En los dos espacios centrales (por debajo de L3 y L4) las fibras se curvaban y extendían postero-superiormente. Las fibras eran más gruesas en los ligamentos de los espacios inferiores en comparación con los superiores. La media de espesor presentada por región fue: Alta $(0,22 \mathrm{~mm})$, Medio $(0,37 \mathrm{~mm})$ y L5-S1 $(0,72 \mathrm{~mm})$. Los ligamentos en mujeres fueron ligeramente más delgados. También se observó que las fibras de los ligamentos interespinosas se adhieren a las superficies internas del ligamento supraespinoso. La unión de los ligamentos en L5-S1 eran relativamente más verticales y robustas. En ningún caso se observó ausencia o cavitaciones de los ligamentos, excepto en un caso con ligamento bilaminar a nivel L3-L4. La anatomía de los ligamentos interespinosos señala su probable rol en la restricción de la flexión aguda en la columna lumbar.

PALABRAS CLAVE: Flexión lumbar; Proceso espinoso; Ligamento supraespinoso.

\section{REFERENCES}

Adams, M. A.; Hutton, W. C. \& Stott, J. R. The resistance to flexion of the lumbar intervertebral joint. Spine, 5(3):245-53, 1980.

Apsden, R. M.; Borstein N. M. \& Hukins, D. W. Collagen organisation in the interspinous ligament and its relationship to tissue function. J. Anat., 155:141-51, 1987.

Bedbrook, G. M. Are cervical spine fractures ever unstable? J. West. Orthop. Assoc., 6(1):7-29, 1969.

Halliday, D. R.; Sullivan C. R.; Hollinshead, W. H. \& Bahn, R. C. Torn cervical ligaments:necropsy examination of the normal cervical region of the spinal column. J. Trauma, 4:219-32, 1964.
Heylings, D. J. Supraspinous and interspinous ligaments of the human lumbar spine. J. Anat., 125(Pt. 1):127-31, 1978.

Hindle, R. J.; Pearcy, M .J. \& Cross, A. Mechanical function of the human lumbar interspinous and supraspinous ligaments. $J$. Biomed. Eng., 12(4):340-4, 1990.

Holdsworth, F. Fractures, dislocations, and fracture-dislocations of the spine. J. Bone Joint Surg. Am., 52(8):1534-51, 1970.

Hukins, D. W. L. \& Meakin, J. R. Relationship between structure and mechanical function of the tissues of the intervertebral joint. Am. Zool., 40(1):42-50, 2000. 
Myklebust, J. B.; Pintar, F. A.; Yoganandan, N.; Cusick, J. F.; Maiman, D.; Myers, T. J. \& Sances, A. Jr. Tensile Strength of Spinal Ligaments. Spine, 13(5):526-31, 1988.

Noyes, R. M.; Delucas, J. L. \& Torvik, P. J. Biomechanics of Anterior Cruciate Ligament Failure: An Analysis of Strain-Rate Sensitivity and Mechanisms of Failure in Primates. J. Bone Joint Surg. Am., 56(2):236-53, 1974.

Pintar, F. A.; Yoganandan, N.; Myers, T.; Elhagediab, A. \& Sances, A. Jr. Biomechanical properties of human lumbar spine ligaments. J. Biomech., 25(11):1351-6, 1992.

Rissanen, P. M. The surgical anatomy and pathology of the supraspinous and interspinous ligaments of the lumbar spine with special reference to ligament ruptures. Acta Orthop. Scand., 46:1-100, 1960.

Scapinelli, R.; Stecco, C.; Pozzuoli, A.; Porzionato, A.; Macchi, V.; \& De Caro, R. The Lumbar Interspinous Ligaments in Humans: Anatomical Study and Review of the Literature. Cells Tissues Organs, 183(1):1-11, 2006.

Silver, P. H. S. Direct observations of changes in tension in the supraspinous and interspinous ligaments during flexion and extension of the vertebral column of man. J. Anat., 88:550, 1954.

Tesh, K. M.; Shaw, D. J.; \& Evans, J. H. The abdominal muscles and vertebral stability. Spine, 12(5):501-8, 1987.

White, A. A. \& Panjabi, M. M. Clinical Biomechanics of the Spine. Philadelphia, J. B. Lippincott Company, 1978. pp.18-23.

\author{
Correspondence to: \\ Dr. Niladri Kumar Mahato \\ Associaate Professor \\ Department of Anatomy \\ SRM Medical College \\ Kattankulathur, Kanchipuram District \\ Tamil Nadu, 603203 \\ INDIA
}

Email: mahatonk@yahoo.co.in

Received: 24-12-2011

Accepted: 22-10-2012 